\title{
Effect of inhalation exposure regimen on DNA binding potency of 1,2-dichloroethane in the rat
}

\author{
Amadeus Baertsch, Werner K. Lutz, and Christian Schlatter \\ Institute of Toxicology. Swiss Federal Institute of Technology and University of Zurich, CH-8603 Schwerzenbach, Switzerland
}

Received May 18, 1990/Accepted November 13, 1990

\begin{abstract}
Dichloroethane (DCE) was reported to be carcinogenic in rats in a long-term bioassay using gavage in com oil ( 24 and $48 \mathrm{mg} / \mathrm{kg} /$ day), but not by inhalation (up to $150-250 \mathrm{ppm}, 7 \mathrm{~h} /$ day, 5 days/week). The daily dose metabolized was similar in the two experiments. In order to address this discrepancy, the genotoxicity of DCE was investigated in vivo under different exposure conditions. Female F-344 rats (183-188 g) were exposed to $[1,2-14 \mathrm{C}]-$ DCE in a closed inhalation chamber to either a low, constant concentration $(0.3 \mathrm{mg} / \mathrm{l}=80 \mathrm{ppm}$ for $4 \mathrm{~h})$ or to a peak concentration (up to $18 \mathrm{mg} / \mathrm{l}=4400 \mathrm{ppm}$ ) for a few minutes. After $12 \mathrm{~h}$ in the chamber, the dose metabolized under the two conditions was $34 \mathrm{mg} / \mathrm{kg}$ and $140 \mathrm{mg} / \mathrm{kg}$. DNA was isolated from liver and lung and was purified to constant specific radioactivity. DNA was enzymatically hydrolyzed to the $3^{\prime}$-nucleotides which were separated by reverse phase HPLC. Most radioactivity eluted without detectable or with little optical density, indicating that the major part of the DNA radioactivity was due to covalent binding of the test compound. The level of DNA adducts was expressed in the dose-normalized units of the Covalent Binding Index, $C B I=\mu$ mol adduct per mol DNA nucleotide/mmol DCE per $\mathrm{kg}$ body wt. In liver DNA, the different exposure regimens resulted in markedly different CBI values of 1.8 and 69, for "constant-low" and "peak" DCE exposure levels. In the lung, the respective values were 0.9 and 31 . It is concluded that the DNA damage by DCE depends upon the concentration-time profile and that the carcinogenic potency determined in the gavage study should not be used for low-level inhalation exposure.
\end{abstract}

Key words: 1,2-Dichloroethane - Carcinogens - DNA binding - Rat - Inhalation - Dose response

\section{Introduction}

Two carcinogenicity studies have been performed with 1,2-dichloroethane (DCE). Apart from strain differences, the major disparity in methodology was the route of application. While the NCI study (NCI 1978) used oral gavage, the Bologna Tumor Center study (Maltoni et al. 1980) used inhalation.

The NCI bioassay showed a significant increase in a variety of tumors in Osborne-Mendel rats and B6C3F1 mice, including squamous cell carcinoma of the forestomach and hemangiosarcoma in male rats, adenocarcinoma of the mammary gland in female rats, mammary adenocarcinoma in female mice and alveolar and bronchiolar adenoma in mice of both sexes. Tumorigenic potencies of DCE expressed as TD 50 values were estimated to be $7 \mathrm{mg} \mathrm{DCE} / \mathrm{kg} /$ day in rats and about $70 \mathrm{mg} \mathrm{DCE} / \mathrm{kg} /$ day in mice (Hooper et al. 1980).

Exposing Sprague-Dawley rats and Swiss mice to 5, 10 , 50 or $150-250 \mathrm{ppm}$ DCE, $7 \mathrm{~h}$ per day, 5 days per week, for 78 weeks, the inhalation study failed to produce any evidence of treatment-related tumor induction (Maltoni et al. 1980). The summary TD 50 were $>297$ and $>86,>4050$ and $>1210 \mathrm{mg} \mathrm{DCE} / \mathrm{kg} /$ day for male and female rats, and male and female mice, respectively (Hooper et al. 1980).

DCE was weakly but reproducibly mutagenic in Salmonella typhimurium (WHO 1987) without metabolic activation. A stronger positive response in TA 1535 and TA 100 resulted from the presence of a liver metabolic activation system due to conjugation with glutathione, catalyzed by glutathione S-transferase (Rannug 1980; van Bladeren et al. 1981).

The potential for covalent binding of DCE to DNA in vivo was investigated by several authors (Reitz et al. 1982; Arfellini et al. 1984; Inskeep et al. 1986). Following i.p. administration of DCE to Sprague-Dawley rats, the major DNA adduct formed in the liver was S-[2-(guanyl-7)ethyl]glutathione (Inskeep et al. 1986). Thus, glutathione conjugation has resulted in an electrophilic intermediate [the half-mustard S-(2-chloroethyl)glutathione and the epi- 


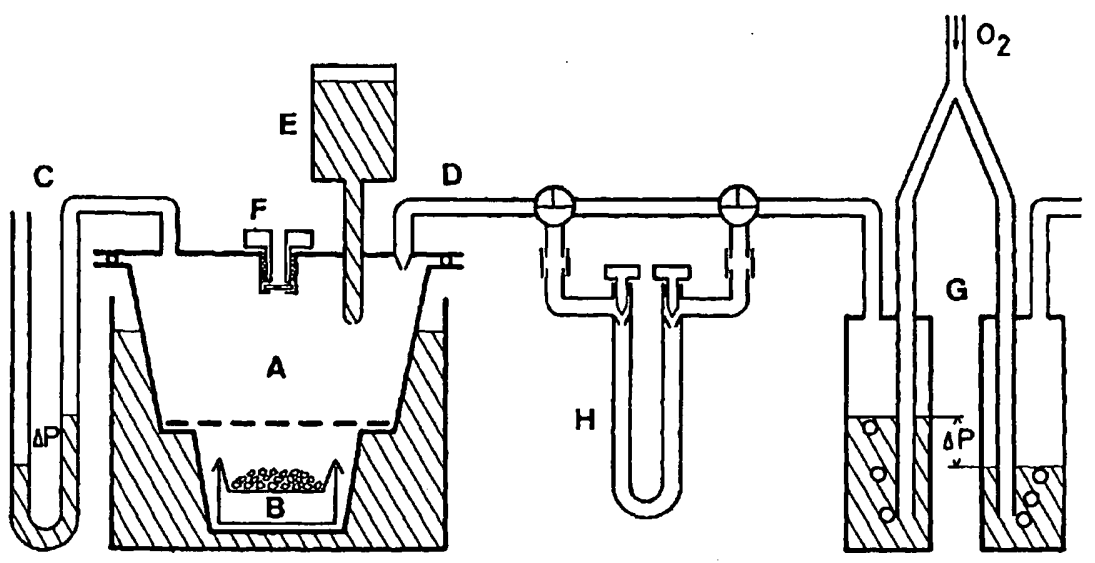

Fig. 1. Schematic representation of the closed inhalation chamber used. The components are: $A$, chamber with a volume of 2.03 I (net gas volume $1.85 \mathrm{I}) ; B$, soda lime to adsorb carbon dioxide; $C$, manometer. The chamber $A$ was maintained at a negative pressure determined by the different filling levels in $\mathrm{G} ; D$, oxygen inlet; $E$, water bottle; $F$, septum holder; $G$, impingers regulating the oxygen supply; $H$, U-tube for freezing out and subsequent application of the test compound sulfonium ion derived] which can react with nucleophilic centers in DNA.

In view of the complex activation and inactivation processes governing the formation of DNA binding, the possibility was considered that different blood levels could result in quantitative metabolic differences and different levels of genotoxicity. Some information along this line was deduced from the work of Storer et al. (1984) with mice. They reported on single-strand breaks induced in liver DNA after oral and intraperitoneal administration of DCE $(100-150 \mathrm{mg} / \mathrm{kg})$ but not after inhalation at up to $500 \mathrm{ppm}$.

Administration of DCE by oral gavage or by injection results in peak blood levels, whereas inhalation exposure to constant concentrations produces a steady burden of the organism. With exposure in a closed inhalation chamber, different concentration-time profiles can be generated to simulate the difference between peak-like administration and continuous low-level exposure. We have therefore investigated whether DNA adduct formation by DCE in rats is dependent on the concentration-time course during inhalation, the most important route of human exposure. One group of rats was exposed to a continuous low concentration of $\left[{ }^{14} \mathrm{C}\right] \mathrm{DCE}$ in the atmosphere. Another group was exposed to high initial concentrations of $\left[{ }^{14} \mathrm{C}\right] \mathrm{DCE}$ in the atmosphere, leading to high peak blood levels of DCE. After $12 \mathrm{~h}$, the level of DNA adducts was determined in liver and lung and expressed per dose metabolized, in the units of the Covalent Binding Index (CBI).

\section{Materials and methods}

\section{Test compound}

Unlabelled DCE from Merck, Darmstadt, FRG, had a purity of $>99.3 \%$ as determined by gas chromatography. Four ampoules, each containing $6.2 \mathrm{mg}(0.50 \mathrm{mCi} ; 8.0 \mathrm{mCi} / \mathrm{mmol})\left[1,2-{ }^{14} \mathrm{C}\right] \mathrm{DCE}$ (Lot Nr. 107F9253) were obtained from Pathfinder Laboratories, Sigma Chemical Company, St Louis, Missouri. Three months before use, gas chromatography performed by Pathfinder Laboratories had demonstrated a radiochemical purity exceeding $98 \%$. In order to check the radiochemical purity at the time of administration, air samples were taken from the inhalation chamber and injected in $1 \mathrm{ml}$ ampoules containing 50\% aqueous methanol. Aliquots were subjected to HPLC separations on a Lichrosphere RP 18
$(5 \mu \mathrm{m})$ column, eluted with methanol/water $(1+1)$ at a flow rate of $1.5 \mathrm{ml} / \mathrm{min}$. Fractions of $1 \mathrm{~min}$ were collected and counted for radioactivity after addition of $10 \mathrm{ml}$ Insta-Gel (Packard) in a Packard scintillation counter Tricarb $460 \mathrm{CD}$. A total of $99 \%$ of the eluted radioactivity was found within one peak at the DCE retention time.

\section{Animals}

Female F-344 rats [CDF(F-344)/Cr1BR] were obtained from Charles River Wiga, Sulzfeld, FRG, with weights in the range of $146-150 \mathrm{~g}$. They were held two per macrolone cage on sawdust for 1 month of acclimatisation. They were fed Haltungsdiät "A" No. 343, Klingental Muhle AG, Kaiseraugst, Switzerland, ad libitum and had free access to tap water.

\section{Closed inhalation chamber}

A closed inhalation system described by Bolt et al. (1976) and modified according to Lutz and Schlatter (1978) was used (Fig. 1). The CO exhaled by the animal was adsorbed on soda lime. The resulting reduced pressure was balanced by a supply of oxygen. This gas flow was also used for the transport of DCE from the U-tube $(\mathrm{H})$ into the chamber. DCE had first been trapped in the U-tube $(H)$ : the ampoules containing radioactive DCE were cooled with liquid nitrogen, opened and quickly enclosed in a round bottomed flask. For the exposures to "peak" concentrations, the flask also contained the unlabelled DCE. The flask was connected to the U-tube on a vacuum line. At a pressure of about $10^{3} \mathrm{~Pa}_{1}$ a waiting period of $30 \mathrm{~min}$ was sufficient for complete transfer and freezing out of the compound. The two teflon screw stoppers of the $\mathrm{U}$-tube were closed, the tube was disconnected from the vacumm line and connected to the by-pass in the oxygen supply stream.

\section{Treatments}

Two different types of exposure were used:

a) "Constant-low" exposure. With rats nos 1 and 2, the U-tube ( $\mathrm{H}$ in Fig. 1) containing $6.2 \mathrm{mg}(0.50 \mathrm{mCi})\left[{ }^{14} \mathrm{C}\right] \mathrm{DCE}$ was immersed in an ethanol bath kept at a temperature between $-45^{\circ} \mathrm{C}$ and $-55^{\circ} \mathrm{C}$ by adding liquid nitrogen:

b) "Peak" exposure. In the exposures of rats nos 3 and 4, $6.2 \mathrm{mg}$ $(0.50 \mathrm{mCi})\left[{ }^{14} \mathrm{C}\right] D C E$ together with 42.9 or $45.4 \mathrm{mg}$ inactive DCE was placed in the U-tube and heated to $30^{\circ} \mathrm{C}$ in a water bath.

After placing a rat in the chamber and waiting for a few minutes until the pressure started to fall, the teflon three-way valves of (D) were switched to the U-tube while the pressure in the chamber further decreased. Oxygen was let into the tube by opening the right-hand screw 
stopper of $(\mathrm{H})$ and finally, by opening the other stopper, the reduced pressure in the chamber was brought back to normal by the stream of oxygen carrying the DCE along.

\section{Kinetics}

At different times after DCE influx, $0.50 \mathrm{ml}$ of the chamber atmosphere was withdrawn with a gas-tight syringe and loaded onto the packed column $\left(4^{\prime} \times 1 / 8^{\prime \prime}\right.$, DC 200 on CHROM-P) of a gas chromatograph GOW-MAC model 750 equipped with FID. A column temperature of $45^{\circ} \mathrm{C}$ and a nitrogen carrier gas pressure of $1.0 \mathrm{~atm}$ resulted in a retention time for DCE of $2 \mathrm{~min}$. Amber glass bottles capped with rubber septa and containing different amounts of unlabelled DCE served as calibration standards.

At the end of the inhalation exposures to labelled DCE, one half of the chamber was cleaned with a paper towel containing toluene and counted for radioactivity. Less than $0.005 \%$ of the applied radioactivity was found to be adsorbed on the inner glass surface of the chamber. The fur of the animals retained less than $1 \%$ of the dose metabolized, as determined by scintillation counting of a small area of fur.

\section{Metabolized dose}

In the situation with "constant-low" exposure, rats completeley metabolized the DCE placed in the U-tube and no DCE was detected in the chamber atmosphere at the end of the experiment. With "peak" exposure to a larger exposure dose, some DCE remained in the chamber at the end of the treatment, indicating that the metabolism was not complete. In this case, the DCE dose metabolized was estimated as illustrated in Fig. 2. For rat no. 3, for instance, the total amount of DCE in the U-tube was $49.1 \mathrm{mg}$. The amount of DCE in the chamber atmosphere was calculated from the measured concentrations and the chamber volume. It dropped from 7.80 to $4.36 \mathrm{mg}$ between 206 and $716 \mathrm{~min}$. At time 0 , and under the assumption of a zero-order decrease, $9.1 \mathrm{mg} \mathrm{DCE}$ are calculated for the chamber atmosphere. Based on a total of $49.1 \mathrm{mg}$ DCE available at time zero, a ratio $40: 9=4.4$ follows for the equilibrium partition between rat and chamber atmosphere. Using this ratio, the amount of DCE in the animal can be calculated for the time of death $\mathrm{t}=732 \mathrm{~min}$ to be $18.2 \mathrm{mg}$. After deduction of the DCE residue remaining in the chamber, the metabolized dose amounts to $26.8 \mathrm{mg}$.

\section{Isolation of DNA}

After $12 \mathrm{~h}$ in the inhalation chamber, the animals were killed by open heart puncture under ether anaesthesia. Livers and lungs were excised and homogenized in a teflon Potter-Elvehjem-type homogenizer at $4^{\circ} \mathrm{C}$. DNA was isolated according to Sagelsdorff et al. (1983). Essentially, chromatin was precipitated with a non-ionic detergent and the pellets were washed until the suspensions contained less than $1 \mu \mathrm{Ci}$ total radioactivity in order to remove the majority of non-covalently bound radioactivity. Half of the chromatin pellet was homogenized in a lysing medium deproteinated with chloroform/isoamyl alcohol/phenol (CIP). Phenol was removed with diethylether, and the DNA was purified by adsorption on a hydroxylapatite column, dialysis, and precipitation with ethanol. The highly purified DNA was dissolved in $20 \mathrm{mM}$ sodium succinate; $\mathrm{pH} 6.0$, containing $8 \mathrm{mM} \mathrm{CaCl}$. The amount of DNA was determined assuming an absorbance of 20 at $260 \mathrm{~nm}$ for a solution of $1 \mathrm{mg} \mathrm{DNA} / \mathrm{ml}$. Scintillation counting was performed on an aliquot of the DNA solution after addition of $10 \mathrm{ml}$ Insta-Gel (Packard).

For repurification, the DNA solution was mixed with $25 \mathrm{ml}$ lysing medium, extracted twice with CIP and diethylether, dialysed and precipitated with ethanol. The DNA was dissolved, and the specific radioactivity of DNA was determined as described above.
Total

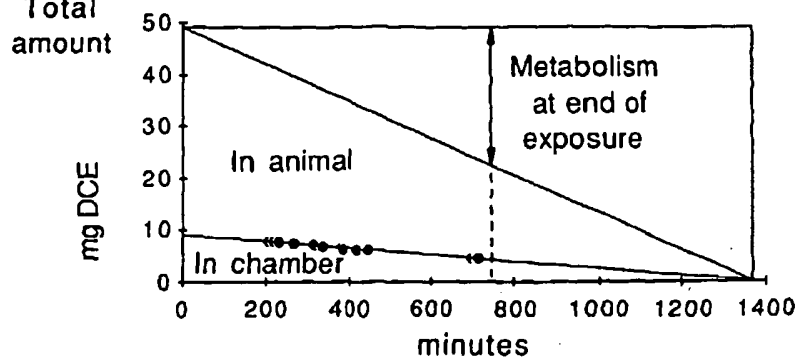

Fig. 2. Schematic illustration of the procedure to calculate the metabolized dose in the closed inhalation chamber. The amount of DCE in the chamber atmosphere (calculated from the measured concentrations and the chamber volume) is extrapolated to time zero. The ratio $\mathrm{DCE}_{\text {tot }}$ to

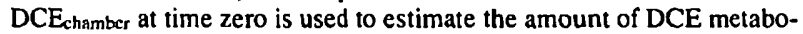
lized at the time of death, on the assumption of equilibrium conditions for DCE between animal and chamber atmosphere. Data points taken from rat no. 3

\section{Control experiments}

Control animals nos 5 and 6 were exposed to unlabelled DCE under conditions of "peak" and "constant-low" exposure, respectively. The organs were used for the following experiments:

a) Background radioactivity. DNA was isolated from rat no. 5. The radioactivity count - upon comparison with historical controls - was used to show that the work-up of the DNA samples was performed without external contamination with radiolabel;

b) Binding in vitro. The chromatin pellet isolated from rat no. 6 was incubated at $4^{\circ} \mathrm{C}$ for $15 \mathrm{~min}$ with the radiolabelled supernatant of the first chromatin precipitation step of the DNA preparation from radiolabeltreated animal no. 3. This checks whether radiolabel could bind to or contaminate DNA during the process of DNA isolation.

Specific activity of contaminating protein. Chromatin protein was precipitated with acetone from the first CIP extract and dissolved in $1 \%(\mathrm{w} / \mathrm{v})$ aqueous SDS. Precipitation and solution steps were repeated 4 times. The last solution was diluted to $0.1 \%$ SDS and $1 \mathrm{ml}$ was used for the scintillation counting. The amount of protein was determined with the Folin reagent.

\section{Analysis of nucleotides by reverse phase chromatography}

DNA in $8 \mathrm{mM} \mathrm{CaCl}, 20 \mathrm{mM}$ sodium succinate buffer, $\mathrm{pH} 6.0$, was digested enzymatically with micrococcal endonuclease (Sigma no. N3755; E. C. 3.1.31.1.; 5 units/mg DNA) and spleen exonuclease (Boehringer Mannheim no. 108 251; E. C. 3.1.16.1; 0.05 units/mg DNA) for $16-18 \mathrm{~h}$ at $37^{\circ} \mathrm{C}$. The resulting nucleotide mixture was separated by HPLC on a Lichrosorb RP $18(7 \mu \mathrm{m})$ column $(8 \mathrm{~mm} \times 250 \mathrm{~mm})$, eluted with $10 \mathrm{mM}$ ammonium formate buffer, $\mathrm{pH} 5.8$ containing $3 \%$ methanol for $10 \mathrm{~min}$, followed by a linear gradient to $100 \%$ methanol in $40 \mathrm{~min}$. The flow rate was $3.5 \mathrm{ml} / \mathrm{min}$. The optical density was recorded at $254 \mathrm{~nm}$. In general, fractions of 2 min were collected. In the regions of the natural nucleotides the fractions were taken manually whenever optical density appeared. The retention times for the natural deoxynucleotides, deoxycytidine- $3^{\prime}$-monophosphate, deoxyguanosine- $3^{\prime}$-monophosphate, thymidine- $3^{\prime}$-monophosphate and deoxyadenosine- $3^{\prime}$-monophosphate (abbreviated to $\mathrm{dCp}, \mathrm{dGp}, \mathrm{Tp}$ and $\mathrm{dAp}$ ) were $4,5,6$, and 12 min, respectively.

The concentration of each deoxynucleotide in the fractions was determined by UV spectroscopy before Insta-Gel was added. Optical densities of $29,38,29$, and 44 for $1 \mathrm{mg} / \mathrm{ml} \mathrm{dCp}, \mathrm{dGp}, \mathrm{Tp}$, and dAp, respectively, were used. For the mixture of nucleosides obtained from DNA, a value of 30 was used. Methanol or water was added to provide homogeneous samples for liquid scintillation counting in $10 \mathrm{ml}$ Insta-Gel.

The background radioactivity was determined from an analysis of an unlabeled DNA digest. The limit of detection of $\left[{ }^{14} \mathrm{C}\right]$ radioactivity in a 


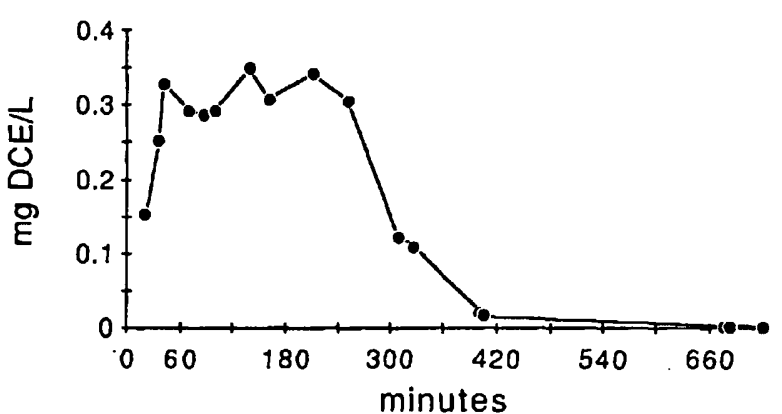

Fig. 3. Time-course of the DCE concentration in the inhalation chamber with rat no. 2. The U-tube of the inhalation system was cooled to $-50 \pm 5^{\circ} \mathrm{C}$ to reduce the vapour pressure and slow down the transportation rate of radiolabelled DCE into the chamber. A concentration of $0.3 \mathrm{mg} /$ corresponds to $80 \mathrm{ppm}$

fraction was $1.8 \mathrm{cpm}$ above background (at the level of 2 standard deviations). This figure was derived from the statistics of radioactivity counting $(2 \mathrm{SD}=0.8 \mathrm{cpm}$ at $3 \times 30 \mathrm{~min}$ counting time, multiplied with the square root of 2 for the difference formed between sample and background), plus the maximum observed vial-to-vial difference of $0.7 \mathrm{cpm}$ (determined with a counting time of $1000 \mathrm{~min}$ per vial).

\section{Calculations}

The level of DNA adduct formation was normalized to the dose, by expression in the units of the Covalent Binding Index $(\mathrm{CBI})=\mu \mathrm{mol}$ adduct per mol nucleotide/mmol DCE per $\mathrm{kg}$ body (Lutz 1979). These molar units were calculated from radioactivity data by the following conversion: $\mathrm{CBI}=(\mathrm{dpm}$ DCE as aducts per mg DNA $) /(\mathrm{dpm}$ DCE metabolized per $\mathrm{kg}$ body) $\times 3.09 \times 10^{8}$ on the basis of an average molecular weight of 309 for a nucleotide in DNA.

\section{Results}

\section{Kinetics and doses metabolized}

"Constant-low" exposure: The slow, steady flow of DCE to the chamber resulted in a concentration level of 0.28 $0.35 \mathrm{mg} \mathrm{DCE} / 1$ air (see Fig. 3 for time-course with rat no. 2). After the first $4 \mathrm{~h}$, no DCE was left in the U-tube and the concentration decreased due to metabolic disappearance of DCE. After $12 \mathrm{~h}$, at the end of the experiment, the minute concentration in the chamber atmosphere ( $0.0016 \mathrm{mg} \mathrm{DCE} / \mathrm{l}$ air) indicated that the entire sample of $6.2 \mathrm{mg}$ DCE had been metabolized.

"Peak" exposure. The concentration-time course of DCE in the chamber atmosphere, as seen with rat no. 3 , is depicted in Fig. 4. Three phases can be distinguished. During the first $20 \mathrm{~min}$, DCE was transported to the chamber and the DCE concentration increased rapidly. The maximum amount of DCE measured in the chamber atmosphere was $34 \mathrm{mg}$ (69\% of the chemical placed in the U-tube). The next $3 \mathrm{~h}$ were governed primarily by uptake and distribution of DCE in the rat. In the last $7 \mathrm{~h}$, a slow disappearance from the atmosphere was observed. Pharmacokinetic data indicate that this decrease was due to

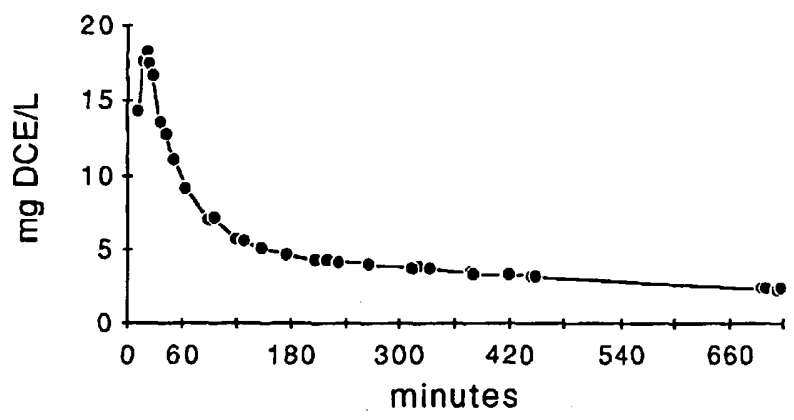

Fig. 4. Time-course of the DCE concentration in the inhalation chamber with rat no. 3 . In order to achieve a high initial concentration in the chamber atmosphere, the $U$-tube of the inhalation system containing radiolabelled DCE was heated to $30^{\circ} \mathrm{C}$. A concentration of $18 \mathrm{mg} /$ corresponds to $4400 \mathrm{ppm}$

DCE metabolism (Reitz et al. 1982; Spreafico et al. 1980). Using the calculation described before (see Fig. 2), rats nos. 3 and 4 metabolized 26.8 and $24.9 \mathrm{mg} \mathrm{DCE}$, respectively.

\section{DNA radioactivity}

Radioactivity was clearly detectable in all DNA samples obtained from livers (Table 1) and lungs (Table 2) of treated animals. In order to remove radioactivity which was not covalently bound, DNA was repurified until the specific radioactivity remained constant within $\pm 10 \%$ (twice for liver; once for lung).

Radioactivity associated with DNA isolated from an animal that has been treated with a radiolabelled substance is not necessarily due to covalent interactions of the test compound with DNA. It could be derived from additional sources:

(i) Interaction of the test compound and its metabolites with DNA during the isolation procedure. This contribution must be small because the data of the respective control experiments given in the column headed "Binding in vitro" of Tables 1 and 2 show that the radioactivity of the DNA arising from the work-up was not significantly measurable.

(ii) Contamination of DNA with protein. DCE and its radiolabelled metabolites interacted with chromatin protein. The specific radioactivities ranged between 1000 and $1600 \mathrm{dpm} / \mathrm{mg}$ protein in the liver and between 400 and $1100 \mathrm{dpm} / \mathrm{mg}$ in the lung. This was not more than a factor of 20 higher than the specific activity encountered in DNA. In view of the maximum possible contamination of our DNA with $0.2 \%$ protein (Caviezel et al. 1984), the specific radioactivities were too low for protein contamination to contribute substantially to the DNA radioactivity.

(iii) Biosynthetic incorporation of radioactivity into DNA and protein. This is a more likely source of radioactivity if the compound administered is degraded to small molecules able to enter the pool of nucleic acid precursors. Analysis of the nucleotides was required to show to what extent incorporation of the radiolabel during DNA synthesis contributed to the total DNA radioactivity. 
Table 1. Radioactivity (RA) in liver DNA isolated from female F-344 rats following $12 \mathrm{~h}$ exposure to "constant-low" and "peak" concentrations of $\left[{ }^{14} \mathrm{C}\right] 1,2$-dichloroethane (DCE) by inhalation

\begin{tabular}{|c|c|c|c|c|c|c|}
\hline \multirow[t]{3}{*}{ Type of experiment } & \multirow{2}{*}{\multicolumn{2}{|c|}{$\begin{array}{l}\text { Exposure to "constant-low" } \\
\text { concentration of }\left[{ }^{14} \mathrm{C}\right] \mathrm{DCE} \\
\text { (see Fig. } 3 \text { for time-course) }\end{array}$}} & \multirow{2}{*}{\multicolumn{2}{|c|}{$\begin{array}{l}\text { Exposure to "peak" concentra- } \\
\text { tion of }\left[{ }^{14} \mathrm{C}\right] \mathrm{DCE} \\
\text { (see Fig. } 4 \text { for time-course) }\end{array}$}} & \multicolumn{2}{|l|}{ Controls } \\
\hline & & & & & \multirow{2}{*}{$\begin{array}{l}\begin{array}{l}\text { Background } \\
\text { radioactivity }\end{array} \\
\text { Rat no. } 5\end{array}$} & \multirow{2}{*}{$\begin{array}{l}\begin{array}{l}\text { Binding } \\
\text { in vitro }\end{array} \\
\text { Rat no. } 6\end{array}$} \\
\hline & Rat no. 1 & Rat no. 2 & Rat no. 3 & Rat no. 4 & & \\
\hline Animal weight (g) & 184 & 183 & 188 & 188 & 175 & 188 \\
\hline $\begin{array}{l}\text { Dose metabolized } \\
(\mathrm{mg} / \mathrm{kg})\end{array}$ & 33.5 & 33.7 & 143 & 133 & 124 & 38.0 \\
\hline $\begin{array}{l}\text { RA metabolized } \\
(\mathrm{dpm} / \mathrm{kg})\end{array}$ & $6.03 \times 10^{9}$ & $6.07 \times 10^{9}$ & $3.22 \times 10^{9}$ & $2.85 \times 10^{9}$ & 0 & 0 \\
\hline $\begin{array}{l}\text { RA in the liver } \\
\text { (\% of total body burden) }\end{array}$ & 2.6 & 1.6 & 5.1 & 4.8 & - & - \\
\hline $\begin{array}{l}\text { DNA Ist purification: } \\
\text { Amount in vial } \\
\text { (mg DNA) }\end{array}$ & 0.60 & 0.38 & 0.42 & 0.56 & 0.46 & 0.39 \\
\hline $\begin{array}{l}\text { Gross RA } \\
\text { (cpm) }\end{array}$ & 40.6 & 29.5 & 299 & 428 & 14.7 & 14.4 \\
\hline $\begin{array}{l}\text { Specific RA } \\
\text { (dpm/mg) }\end{array}$ & 55.2 & 50.8 & 849 & 953. & 0 & 0 \\
\hline $\begin{array}{l}\text { DNA 2nd purification: } \\
\text { Specific RA } \\
\text { (dpm/mg) }\end{array}$ & 47.9 & 45.1 & 723 & 793 & 0 & 0 \\
\hline $\begin{array}{l}\text { DNA 3rd purification: } \\
\text { Specific RA } \\
\text { (dpm/mg) } \\
\text { (CBI units) }\end{array}$ & $\begin{array}{r}43.0 \\
2.2\end{array}$ & $\begin{array}{r}42.9 \\
2.2\end{array}$ & $\begin{array}{r}656 \\
63\end{array}$ & $\begin{array}{r}723 \\
79\end{array}$ & -0 & -0 \\
\hline $\begin{array}{l}\text { Nucleotide analyses by reverse } p \\
\text { Recovery of RA } \\
\text { loaded (\%) }\end{array}$ & $\begin{array}{l}\text { ise HPLC } \\
92\end{array}$ & 86 & 94 & 109 & - & - \\
\hline $\begin{array}{l}\text { RA in fractions } \\
\text { with natural nucleotides } \\
\text { (\% of total RA eluted) }\end{array}$ & 22 & 18 & 6 & 0 & - & - \\
\hline $\begin{array}{l}\text { RA due to adduct formatione } \\
\text { (\% of total RA eluted) }\end{array}$ & 78 & 82 & 94 & 100 & - & - \\
\hline $\begin{array}{l}\text { Covalent binding } \\
\text { (CBI units) })^{\mathrm{b}}\end{array}$ & 1.7 & 1.8 & 59 & 79 & - & - \\
\hline
\end{tabular}

a The counting efficiency was $79 \%$

b The Covalent Binding Index (CBI) was defined:

c Sum of the radioactivity in the hatched fractions of Figs. 5 and 6

$\mathrm{CBI}=\mu$ mol adducts / mol DNA nucleotide

\section{Radiolabel in normal nucleotides}

Enzymatic degradation of the DNA to the deoxyribonucleotide-3'-monophosphates and separation of the four natural constituents $\mathrm{dCp}, \mathrm{dG}, \mathrm{Tp}$ and $\mathrm{dAp}$ by reverse phase HPLC resulted in reproducible elution profiles where the natural deoxyribonucleotides were localized by the use of standards and their optical density at $254 \mathrm{~nm}$ (Fig. 5). The small peaks following dAp represented deoxyribonucleosides obtained from partial loss of the 3 -phosphate group from the nucleotides. The $\left[{ }^{14} \mathrm{C}\right]$ radioactivity in each fraction was counted. The concentration of the nucleotides in the fractions with optical density was measured and specific radioactivities were calculated. Radiolabel mea- sured in fractions with low specific radioactivity was assumed to represent biosynthetic incorporation of the radiolabel into the nucleotide skeleton (open bars in Figs. 5 and 6). The respective fraction ranged from undetectable to $22 \%$ in the liver, and from 6 to $44 \%$ in the lung.

\section{DCE-nucleotide adducts: Covalent Binding Indices}

Formation of DNA adducts alters the retention time of the modified nucleotides in the HPLC run. Since DCE-nucleotide adducts have the same (high) specific activity as DCE administered, they are detectable on the basis of radioactivity with little or no optical density. These frac- 
Table 2. Radioactivity (RA) in lung DNA isolated from female F-344 rats following $12 \mathrm{~h}$ exposure to "constant low" and "peak" concentrations of $\left[{ }^{14} \mathrm{C}\right] 1$,2-dichloroethane (DCE) by inhalation. Animal weight, chemical and radioactivity dose metabolized are given in Table 1

\begin{tabular}{|c|c|c|c|c|c|c|}
\hline \multirow[t]{3}{*}{ Type of experiment } & \multirow{2}{*}{\multicolumn{2}{|c|}{$\begin{array}{l}\text { Exposure to "constant-low" } \\
\text { concentration of }\left[{ }^{14} \mathrm{C}\right] \mathrm{DCE} \\
\text { (sce Fig. } 3 \text { for time-course) }\end{array}$}} & \multirow{2}{*}{\multicolumn{2}{|c|}{$\begin{array}{l}\text { Exposure to "peak" concentra- } \\
\text { tion of }\left[{ }^{14} \mathrm{C}\right] \mathrm{DCE} \\
\text { (see Fig. } 4 \text { for time-course) }\end{array}$}} & \multicolumn{2}{|l|}{ Controls } \\
\hline & & & & & \multirow{2}{*}{$\begin{array}{l}\begin{array}{l}\text { Background } \\
\text { radioactivity }\end{array} \\
\text { Rat no. } 5\end{array}$} & \multirow{2}{*}{$\begin{array}{l}\begin{array}{l}\text { Binding } \\
\text { in vitro }\end{array} \\
\text { Rat no. } 6\end{array}$} \\
\hline & Rat no. 1 & Rat no. 2 & Rat no. 3 & Rat no. 4 & & \\
\hline $\begin{array}{l}\text { RA in the lungs } \\
\text { (\% of total body burden) }\end{array}$ & 0.043 & 0.041 & 0.097 & 0.10 & - & - \\
\hline $\begin{array}{l}\text { DNA lst purification: } \\
\text { Amount in vial }\end{array}$ & 0.50 & 0.35 & 0.29 & 0.33 & 0.33 & 0.35 \\
\hline $\begin{array}{l}\text { Gross RA } \\
(\mathrm{cpm})\end{array}$ & 26.1 & 24.6 & 96 & 104 & 13.4 & 15.0 \\
\hline $\begin{array}{l}\text { Specific RA } \\
(\mathrm{dpm} / \mathrm{mg})^{\mathrm{a}}\end{array}$ & 28.4 & 35.2 & 348 & 342 & 0 & 0 \\
\hline $\begin{array}{l}\text { DNA 2nd purification: } \\
\text { Specific RA } \\
\text { (dpm/mg) }^{\mathrm{a}} \\
\text { (CBI units) }^{\mathrm{b}}\end{array}$ & $\begin{array}{r}28.6 \\
1.5\end{array}$ & $\begin{array}{r}36.0 \\
1.8\end{array}$ & $\begin{array}{r}322 \\
31\end{array}$ & $\begin{array}{r}330 \\
36\end{array}$ & $\begin{array}{l}0 \\
-\end{array}$ & $\begin{array}{l}0 \\
-\end{array}$ \\
\hline & \multicolumn{2}{|c|}{ Samples of Rat no. $1 \& 2$ pooled } & Rat no. 3 & Rat no. 4 & Rat no. 5 & Rat no. 6 \\
\hline \multicolumn{7}{|c|}{$\begin{array}{l}\text { Nucleotide analyses by reverse phase HPLC } \\
\text { Recovery of RA }\end{array}$} \\
\hline $\begin{array}{l}\text { RA in fractions } \\
\text { with natural nucleotides } \\
\text { ( } \% \text { of total RA eluted) }\end{array}$ & 44 & & 6 & 6 & - & - \\
\hline $\begin{array}{l}\text { RA due to adduct formation } \\
\text { (\% of total RA eluted) }\end{array}$ & 56 & & 94 & 94 & - & - \\
\hline $\begin{array}{l}\text { Covalent binding } \\
\text { (CBI units) }\end{array}$ & 0.9 & & 29 & 34 & - & - \\
\hline
\end{tabular}

$a, b, c$ For footnotes see legend to Table $]$

tions (emphasized by hatched bars in Figs. 5 and 6) contained $78-100 \%$ and $56-94 \%$ of the total radioactivity eluted in HPLC following hydrolysis of DNA from liver and lung, respectively (Tables 1 and 2). The HPLC profiles also provided evidence for the presence of structurally different DNA adducts, but the separation was limited by the number of fractions and the counts available.

In order to normalize the DNA damage to the dose, the specific radioactivity attributable to DNA adduct formation was now converted to the units of the $\mathrm{CBI}=(\mu \mathrm{mol}$ chemical bound per mol nucleotide/mmol chemical metabolized per $\mathrm{kg}$ body weight) (Lutz 1979). The values are shown in the last line of Tables 1 and 2 . It emerges that exposure to a "peak" concentration resulted in much higher DNA binding potency of DCE than "constant-low" concentration, both for liver (69 versus 1.8) and for lung (31 versus 0.9).

\section{Discussion}

\section{DNA binding potency}

We have shown that the potency of DNA adduct formation in rats after inhalation of DCE is strongly dependent upon the concentration-time course. With peak concentrations reaching up to $4400 \mathrm{ppm}$ in the atmosphere for a few minutes, the CBI was 69 for liver DNA and 31 for lung DNA. The other inhalation regimen, a constant concentration level of about $80 \mathrm{ppm}$ for $4 \mathrm{~h}$, resulted in CBI values lower by a factor of about 40 , both for liver and lung.

The literature values on DNA binding potency after injection of DCE are in accordance with the binding potency of our "peak" exposure regimen: Inskeep and coworkers (1986) have treated rats with a single dose of $150 \mathrm{mg} / \mathrm{kg}\left[1,2-{ }^{14} \mathrm{C}\right] \mathrm{DCE}$ by i.p. injection and have isolated DNA $8 \mathrm{~h}$ later. In the liver, neutral thermal hydrolysis to depurinate 7 -alkylguanines released $78 \%$ of the DNA radioactivity. HPLC analysis showed one major peak migrating with synthetically prepared S-[2-(guanyl-7)ethyl]-glutathione. Two minor radioactivity peaks were also present, one of which was identified as S-[2-(guanyl-7)ethyl]-cysteinylglycine. This structural diversity of adducts could also explain the different peaks found in the present study (Figs. 5 and 6). Expressed in the units of the CBI and assuming complete metabolism of the administered dose, a value of 40 can be calculated for the liver.

Arfellini and coworkers (1984) have published a CBI value of 47 in rat liver DNA, after i.p. administration of 

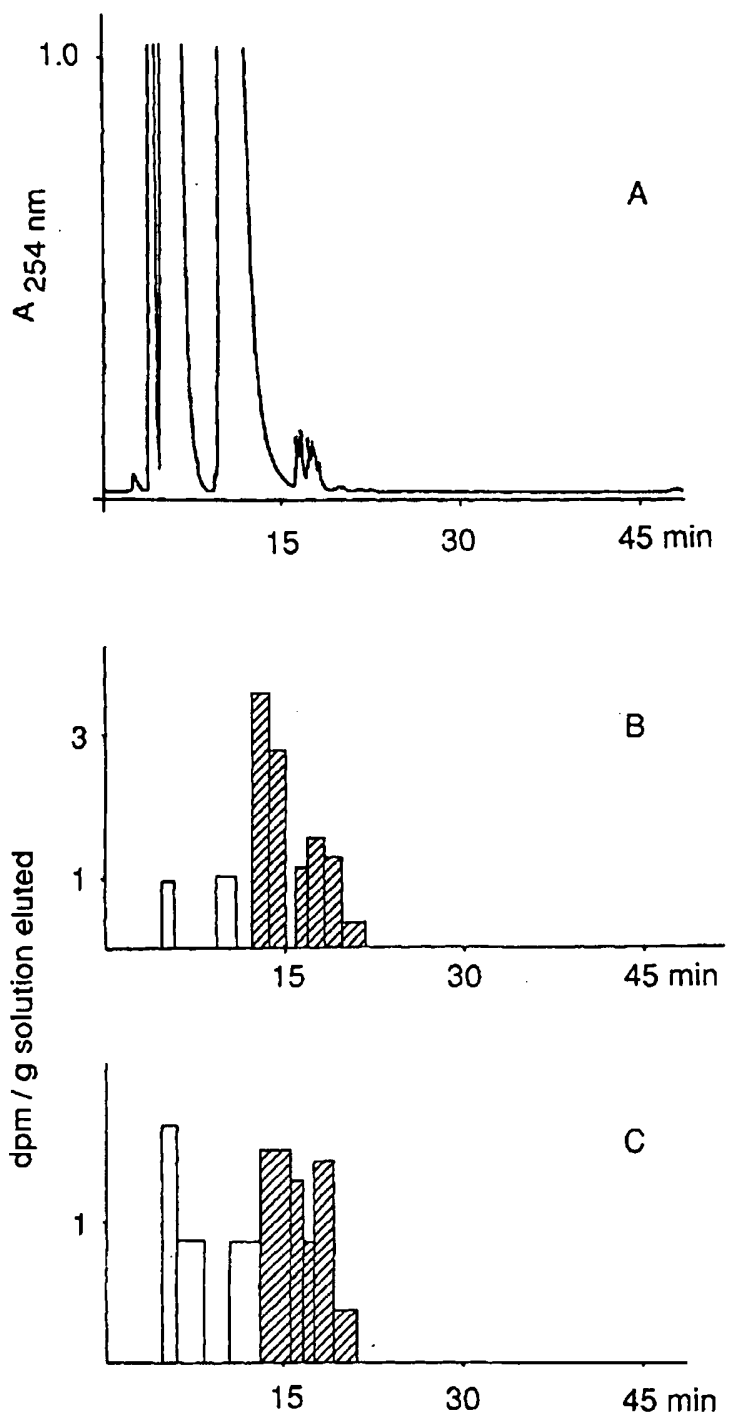

Fig. 5. Reverse phase HPLC elution profiles of deoxyribonucleotides obtained by enzymatic hydrolyses of DNA isolated from F-344 rats following inhalation exposures to "constant-low" concentrations of 1,2$\left[{ }^{14} \mathrm{C}\right]$ dichloroethane. A Absorbance at $254 \mathrm{~nm}$, representing the normal $3^{\prime}$-nucleotides in the order $\mathrm{dCp}, \mathrm{dG}+\mathrm{Tp}, \mathrm{dAp}$ (liver DNA sample of rat no. 2 shown). B $\left[{ }^{14} \mathrm{C}\right]$ Radioactivity profile (liver DNA of rat no. 2). DNA adducts eluting in hatched bars with specific radioactivities $>550 \mathrm{dpm} / \mathrm{mg}$. Open bars: $10 \mathrm{dpm} / \mathrm{mg} \mathrm{dGp} \mathrm{and} 28 \mathrm{dpm} / \mathrm{mg} \mathrm{dAp}$. C $\left[{ }^{14} \mathrm{C}\right]$ Radioactivity profile (lung DNA of pool of rats nos $]$ and 2). Specific radioactivities of $>115$ and $15-19 \mathrm{dpm} / \mathrm{mg}$ were measured in hatched and open bars, respectively

DCE to rats. Since they did not account for the level of biosynthetic incorporation of radiolabel into DNA, the true adduct value could be slightly lower.

\section{Metabolic activation and inactivation}

DCE is weakly electrophilic. This reactivity forms the basis of a weak activation independent (direct) mutagenicity in the Ames test. Our findings could therefore be interpreted in terms of a saturation of enzymatic detoxication

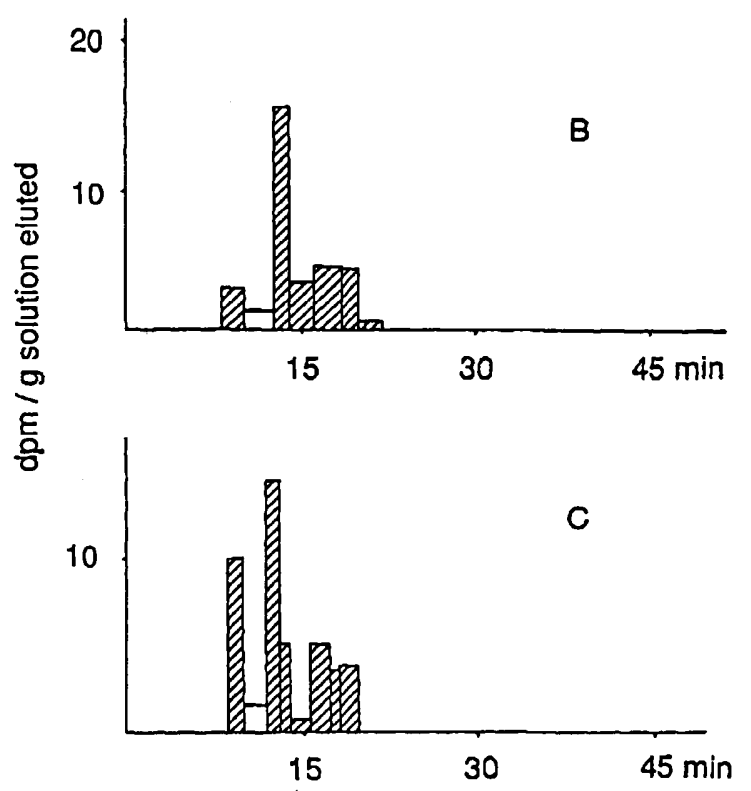

Fig. 6. Reverse phase HPLC elution profiles of deoxyribonucleotides obtained by enzymatic hydrolyses of DNA isolated from F-344 rats following inhalation exposures to "peak" concentrations of 1,2$\left[{ }^{14} \mathrm{C}\right]$ dichloroethane. See Fig. $5 \mathrm{~A}$ for characteristic absorbance profile of normal nucleotides. B $\left[{ }^{14} \mathrm{C}\right]$ Radioactivity profile (liver DNA of rat no. 3). The hatched bar's had specific activities $>40^{\prime} 000 \mathrm{dpm} / \mathrm{mg}$ and represent adducts, the open bar showed $180 \mathrm{dpm} / \mathrm{mg}$. C $\left[{ }^{14} \mathrm{C}\right]$ Radioactivity profile (lung DNA of rat no. 4). The specific radioactivites found in hatched and open bars were $>1070$ and $95 \mathrm{dpm} / \mathrm{mg}$, respectively

above a certain blood level. This explanation cannot be accepted unconditionally because it has been shown that conjugation with glutathione can generate a more reactive electrophile than the parent compound. This situation is opposed to the general understanding of glutathione action and is specific for 1,2-dihaloalkanes. Conjugation with glutathione is not, therefore, a simple inactivation pathway in this case, and saturation does not have to result in an increased DNA damage. Another complicating factor is the fact that a cytochrome P450-dependent pathway can lead to 2-chloroacetaldehyde which can also react with macromolecules. It is therefore as yet unknown whether some inactivation pathway is saturated at high blood levels or whether processes activating DCE to more dangerous DNA-binding metabolites might operate effectively only above a certain concentration.

\section{Oral versus inhalation exposure}

Different genotoxic potency of DCE by the bolus-like administrations (gavage and i.p. injection) versus inhalation has been reported before (Storer et al. 1984). Single-strand breaks and alkali-labile lesions in hepatic DNA were demonstrated $4 \mathrm{~h}$ after p.o. and i.p. administration of $100-$ $150 \mathrm{mg} / \mathrm{kg}$, but not after inhalation at up to $500 \mathrm{ppm}$. Inhalation exposures to 1000 and $2000 \mathrm{ppm}$ DCE caused high mortality after $24 \mathrm{~h}$ and damaged DNA within $4 \mathrm{~h}$, but the possibility that this damage was due to the acute necro- 
genic effects was not excluded. The different level of DNA adduct formation determined in this study is in good agreement with their investigation. The dose metabolized in our "peak" inhalation exposure was similar to the dose which Storer and coworkers administered by gavage; both models of administration probably resulted in a rapid initial increase of DCE in the blood.

The present study indicates that the genotoxic potency of 1,2-dichloroethane strongly depends upon the dosing regimen. The carcinogenic potency determined in the gavage study should not, therefore, be used for low-level inhalation exposure.

\section{References}

Arfellini G, Bartoli S, Colacci A. Mazzullo M, Galli MC, Prodi G, Grilli $S$ (1984) In vivo and in vitro binding of 1,2-dibromoethane and 1,2-dichloroethane to macromolecules in rat and mouse organs. J Cancer Res Clin Oncol 108: 204-213

Bolt HM, Kappus H, Buchter A, Bolt W (1976) Disposition of $\left[1,2-{ }^{14} \mathrm{C}\right]$ vinyl chloride in the rat. Arch Toxicol 35: 153-162

Caviezel M, Lutz WK, Minini U, Schlatter C (1984) Interaction of estrone and estradiol with DNA and protein of liver and kidney in rat and hamster in vivo and in vitro. Arch Toxicol 55: 97-103

Hooper K, Gold LS, Ames BN (1980) The carcinogenic potency of ethylene dichloride in two animal bioassays: a comparison of inhalation and gavage studies. In: Ames B, Infante P, Reitz R (eds) Ethylene dichloride: a potential health risk? Banbury Report, vol 5, Cold Spring Harbor Laboratory, Cold Spring Harbor, NY, pp 65-81

Inskeep PB, Koga N, Cmarik JL, Guengerich FP (1986) Covalent binding of 1,2-dihaloalkanes to DNA and stability of the major DNA adduct, S-[2-(N'-guanyl)ethyl]glutathione. Cancer Res 46: 28392844

Lutz WK (1979) In vivo covalent binding of organic chemicals to DNA as a quantitative indicator in the process of chemical carcinogenesis. Mutat Res 65: 289-356
Lutz WK, Schlatter C (1978) A closed inhalation system for pharmacokinetic and metabolism studies of volatile compounds with small laboratory animals. Arch Toxicol Suppl. 1: 373-375

Maltoni C, Valgimigli L, Scarnato C (1980) Long-term carcinogenic bioassays on ethylene dichloride administered by inhalation to rats and mice. In: Ames B, Infante P, Reitz R (eds) Ethylene dichloride: a potential health risk? Banbury Report, vol 5, Cold Spring Harbor Laboratory, Cold Spring Harbor, NY, pp 3-33

NCI (1978) Bioassay of 1,2-dichloroethane for possible carcinogenicity. Carcinogenesis Technical Report Series No. 55, National Cancer Institute, Bethesda, Md, pp vii, A-1 - B-9

Rannug U (1980) The use of different metabolizing systems in the elucidation of the mutagenic effects of ethylene dichloride in Salmonella. In: Ames B, Infante P, Reitz R (eds) Ethylene Dichloride: a potential health risk? Banbury Report, vol 5, Cold Spring Harbor Laboratory, Cold Spring Harbor, NY, pp 83-95

Reitz RH, Fox TR, Ramsey JC, Quast JF, Langvardt PW, Watanabe PG (1982) Pharmacokinetics and macromolecular interactions of ethylene dichloride in rats after inhalation or gavage. Toxicol Appl Pharmacol 62: 190-204

Sagelsdorff P, Lutz WK, Schlatter C (1983) The relevance of covalent binding to mouse liver DNA to the carcinogenic action of hexachlorocyclohexane isomers. Carcinogenesis 4: 1267-1273

Spreafico F, Zuccato E, Marcucci F, Sironi M, Paglialunga S, Madonna M, Mussini E (1980) Pharmacokinetics of ethylene dichloride in rats treated by different routes and its long-term inhalatory toxicity. In: Ames B, Infante P, Reitz R (eds) Ethylene dichloride: a potential health risk? Banbury report, vol 5, Cold Spring Harbor Laboratory, Cold Spring Harbor, NY, pp 107-133

Storer RD, Jackson NM, Conolly RB (1984) In vivo genotoxicity and acute hepatotoxicity of 1,2-dichloroethane in mice: comparison of oral, intraperitoneal, and inhalation routes of exposure. Cancer Res 44: 4267-4271

Van Bladeren PJ, Breimer DD, Rotteveel-Smijs GMT, de Knijff P Mohn GR, van Meeteren-Wälchli B, Buijs W, van der Gen A (1981) The relation between structure of vicinal dihalogen compounds and their mutagenic activation via conjugation to glutathione. Carcinogenesis 2: $499-505$

WHO (1987) 1,2-Dichloroethane. IPCS International Programme on Chemical Safety. Environmental Health Criteria vol 62, World Health Organization, Geneva, pp 51-55 